\section{Effects of Low-dose Gamma Radiation on Expression of Apoptotic Genes in Rat Peripheral Blood Lymphocyte}

\author{
Zhila Ghorbani ${ }^{1 \oplus}$, Reza Fardid ${ }^{2,3 * \odot}$
}

\begin{abstract}
Background: Exposure to high-dose ionizing radiation is known as a human carcinogen factor, but our information about the effects of low-dose ionizing radiation such as occupational exposures is limited. The main concern of scientific community is biological consequences due to low-dose radiations.

Objective: This study aims to evaluate the effects of low-dose $\gamma$-radiation on expression changes of apoptotic genes (bax and bcl-2) in the rat peripheral blood lymphocytes.

Material and Methods: In this experimental study, 42 adult male rats were classified into 6 groups, which was exposed to various doses values ranged from $20 \mathrm{mGy}$ to $1000 \mathrm{mGy}$ by $\gamma$-rays from a Co-60 source. Blood samples were provided for analysis of gene expression $24 \mathrm{~h}$ after gamma radiation by relative quantitative Reverse Transcription - Polymerase Chain Reaction (RT-PCR). Radiation sensitivity of rat lymphocytes was measured by the bax/bcl-2 ratio as a predictive marker for radio-sensitivity.
\end{abstract}

Results: The results of this study showed that low dose of gamma radiation can induce down-regulation of bax in rat peripheral blood lymphocytes. Despite other mechanisms of cellular radio-protection, changes in expression of these apoptotic genes can be the primary pathway in responses of the lymphocytes radio-protection to the exposure. Our study revealed a significant decrease in the bax/bcl-2 ratio at $50 \mathrm{mGy}$ dose compare to control and the other irradiated groups $(\mathrm{p}<0.05)$.

Conclusion: These results suggest that changes in the bax/bcl-2 ratio especially in radiation workers, as a key factor in apoptosis, can be considered as a biological marker in low-dose gamma radiation.

Citation: Ghorbani Zh, Fardid R. Effects of Low-dose Gamma Radiation on Expression of Apoptotic Genes in Rat Peripheral Blood Lymphocyte. J Biomed Phys Eng. 2021;11(6):693-700. doi: 10.31661/jbpe.v0i0.1166.

\section{Keywords}

Gamma Radiation; Real-Time Polymerase Chain Reaction; Bcl-2-Associated X Protein; Genes, P53; Radiation Sensitivity

\section{Introduction}

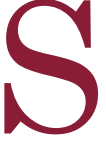
ince the beginning of existence, humans have been exposed to low-dose natural ionizing radiation. Humans exposure by widespread use of ionizing radiation in a variety of fields such as medicine (diagnosis and therapy), industry, agriculture and nuclear weapons
${ }^{1} \mathrm{MSc}$, Radiobiology \&

Radiation Protection,

School of Paramedical

Sciences, Shiraz Univer-

sity of Medical Sciences,

Shiraz, Iran

${ }^{2} \mathrm{PhD}$, Associate Profes-

sor of Medical Physics,

Department of radiology,

School of Paramedical

Sciences, Shiraz Univer-

sity of Medical Sciences,

Shiraz, Iran

${ }^{3} \mathrm{PhD}$, Associate Profes-

sor of Medical Physics,

Ionizing and Non-Ioniz-

ing Radiation Protection

Research Center, School

of Paramedical Sci-

ences, Shiraz University

of Medical Sciences,

Shiraz, Iran

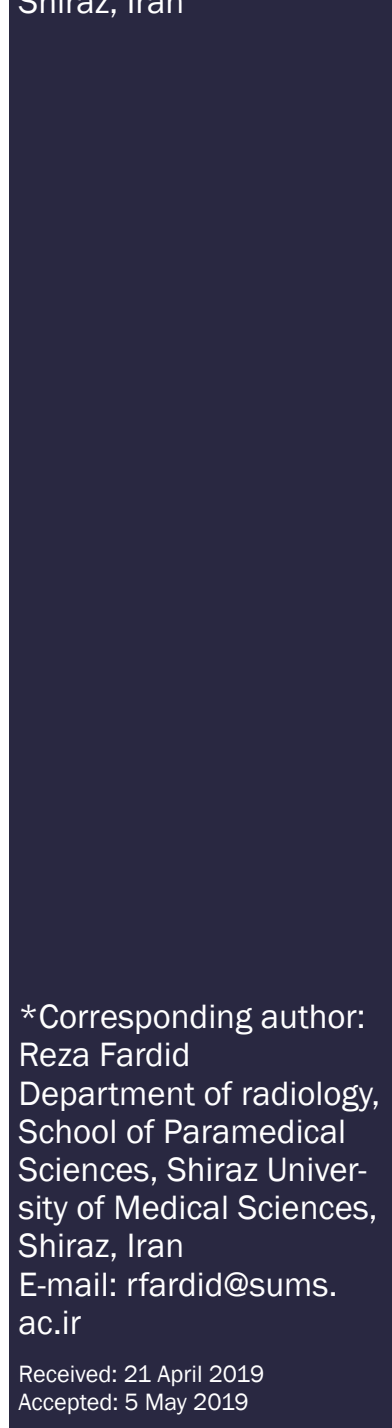


tests has been growing rapidly $[1,2]$. Medical radiation workers in nuclear medicine and radiology centers have been introduced as chronically exposed society of low-dose ionizing radiation. Although high-dose radiation is known to be a human carcinogenic factor inducing various biological effects, the biological effects of low-dose ionizing radiation such as occupational radiation have not been adequately known yet, and the main concern of scientific community is the biological consequences of the radiation [3]. Physical dosimeters such as TLDs, films as well as other devices and methods in accidental and unplanned exposures from natural, medical and occupational resources are not suitable. In such cases, evaluating changes in cellular and molecular level can be a good technique [4-7].

Cellular exposure to ionizing radiation leads to oxidative stress through direct interactions of radiation with DNA, as critical target, or via products of water radiolysis [8,9]. It has been reported that the main mechanism of radiation damage (tumoral and normal tissues) through DNA damage is apoptosis or cell death caused by free radicals $[10,11]$.

In recent years, many researchers have considered these molecular endpoints, such as changes in the expression of genes involved in apoptosis as biological markers of radiation sensitivity [12-18].

P53 gene seems to play a vital role in initiating radiation-induced apoptosis, especially at the onset of apoptosis. Up-regulation of bax gene and its transfer from cytoplasm to mitochondria lead to activation of p53. On the other hand, the anti-apoptotic members of the bcl2 family, such as bcl-2, counteracted the actions of bax and other members of the proapoptotic proteins. Therefore, the bax/bcl2 ratio can be considered as a radio-sensitivity marker [19, 20].

The aim of this study was to evaluate the changes in expression of apoptotic genes (bax, bcl-2 and bax/bcl-2 ratio) in rat peripheral blood lymphocytes following low-dose gam- ma radiation.

\section{Material and Methods}

\section{Rats care and maintenance}

In this experimental study, 8-10 week male Sprague-Dawley rats were purchased from the Center of Comparative \& Experimental medicine, Shiraz university of Medical science, Shiraz, Iran. All animals were kept under controlled standard conditions of temperature (23 $\left.\pm 2{ }^{\circ} \mathrm{C}\right)$, humidity $(55 \pm 5 \%)$, with a 12 -h light and 12-h dark cycle at the center of comparative \& experimental medicine laboratory for two weeks before the start of experiment. Rats were fed based on the standard pellet diet and water was given ad libitum. All experiments were performed in accordance with the guideline of the Ethics Committee of Shiraz University of Medical Sciences.

\section{Experimental design and irradia- tion}

All animals were transferred to cobalt 60-gamma irradiator (Theratron 780, Atomic energy of Canada limited, Canada) facility in the department of radiotherapy, Namazi hospital, Shiraz, Iran. Anesthetized rats were placed in well-ventilated acrylic restrainers and exposed to whole-body gamma radiation of different doses $(10,20,50,100,200$ and $1000 \mathrm{mGy}$ ) at dose rate of $30 \mathrm{cGy} / \mathrm{min}$ with a source skin distance of $80 \mathrm{~cm}(\mathrm{SSD}=80 \mathrm{~cm})$ and fixed field size of $35 \mathrm{~cm} \times 35 \mathrm{~cm}$ at room temperature $\left(23 \pm 2{ }^{\circ} \mathrm{C}\right)$. The doses of gamma radiation selected were based on previous studies [12, 19].

This experiment was performed using 49 rats with 7 rats in each group. Control group did not receive irradiation. The rats in irradiated groups were exposed to whole-body gamma radiation with doses of 10, 20, 50, 100, 200 and $1000 \mathrm{mGy}$, respectively. $24 \mathrm{~h}$ after exposure to gamma irradiation, all the animals were anesthetized with ether, and the blood samples (2 $\mathrm{ml}$ from each animal) were collected from the 
Radio-protective Effects of Low-dose Radiation

heart puncture in EDTA sterile tubes. These blood samples were used for measurement of bcl-2 and bax expression levels using quantitative real-time reverse transcriptase- polymerase chain reaction ( $\mathrm{RT}^{2} \mathrm{PCR}$ or $\left.\mathrm{QPCR}\right)$.

\section{Quantitative real-time RT-PCR (QPCR)}

According to the standard protocol, lymphocyte isolation from each of the blood samples was performed by Ficoll Lymphodex (Innotrain, Germany). Blood was diluted 1:3 with Phosphate-Buffered Saline (PBS) and carefully layered onto the Ficoll in the ratio of 2:1 (Blood + PBS: Ficoll). The blood was centrifuged at room temperature at 3000 RPM for $20 \mathrm{~min}$. The layer was removed and centrifuged at 1400 RPM for 10 min after three times washed with PBS. The supernatant layer was removed and $500 \mu \mathrm{L}$ of PBS was added to the sediment layer (Lymphocyte layer). RNA extraction was performed according to the protocol of RNX-Plus Kit. RNA purity was measured by spectrophotometry at 260/260 $\mathrm{nm}$ ratio $(260 / 280$ ratio $>1.8)$ and integrity was confirmed by electrophoresis on a $1.2 \%$ agarose gel. The DNase I (Thermo Science, USA) was used before cDNA synthesis to remove pollution of RNA with DNA. The synthesis of cDNA was done by the protocol of Revert Aid First Strand cDNA synthesis kit (Fermentase, Lithuania). Moreover, RT PCR was performed with SYBR Green Real Time PCR kit (Yekta tajhiz, Iran) using the plates of 48 wells specialized for Step One ${ }^{\mathrm{TM}}$ ABI machine. Number of cycles and temperature conditions for Real-time PCR were listed in the Table 1.

The comparative CT (threshold cycle) value method was used to measure the relative expression of the genes of interest in each of the samples. Glyceraldehyde-3-phosphate dehydrogenase (GAPDH) was used as housekeeping gene [21].

\section{Statistical analysis}

All results are expressed as mean \pm SEM. The data were analyzed using One-way analysis of variance (ANOVA) followed by Tukey multiple comparison test. A value of $p<0.05$ was considered statistically significant.

\section{Results}

The relative expression level of the bax and bcl-2 gene

Figure 1 shows the levels of bcl-2 gene expression in the six studied groups after $24 \mathrm{~h}$ following exposure of whole-body gamma radiation. Exposure to $20 \mathrm{mGy}$ and $1000 \mathrm{mGy}$ doses in $24 \mathrm{~h}$ after irradiation in comparison with control group resulted in a significant increase of bcl-2 gene expression levels $(p<$ $0.001)$; although the expression of this gene significantly decreased in $100 \mathrm{mGy}$ and 200 mGy doses, $(p<0.001$ and $p<0.01$, respectively).

In the groups exposed to radiation 50, 100 and $200 \mathrm{mGy}$ in comparison with the group exposed to $20 \mathrm{mGy}$, a significant decrease in

Table 1: The time and temperature conditions in the various steps of Real-Time Polymerase Chain Reaction (PCR).

\begin{tabular}{cccc} 
Step & Number of cycle & Temperature ${ }^{\circ} \mathbf{C}$ & Time \\
\hline Denaturation & 1 & 95 & $2 \mathrm{~min}$ \\
\hline Denaturation & & 95 & $30 \mathrm{~s}$ \\
\hline Annealing & 40 & 58 & $30 \mathrm{~s}$ \\
\cline { 1 - 3 } Extension & & 72 & $30 \mathrm{~s}$ \\
\hline Final Extension & 1 & 72 & $5 \mathrm{~min}$
\end{tabular}


expression of Bcl-2 was observed. In contrast, there was a significant increase in the 1000 mGy group compared to the $20 \mathrm{mGy}$ group ( $\mathrm{p}$ $<0.001)$. Bcl-2 gene expression in $1000 \mathrm{mGy}$ exposure showed a significant increase in comparison with exposure to 50, 100 and 200
mGy doses of gamma radiation $(\mathrm{p}<0.001)$.

According to Figure 2, in exposed group to irradiation of 20 and $1000 \mathrm{mGy}$ gamma of cobalt radiation-60 in comparison with the control group, a relative increase of bax apoptosis gene expression was seen $(\mathrm{P}<0.05$ and $\mathrm{p}<$

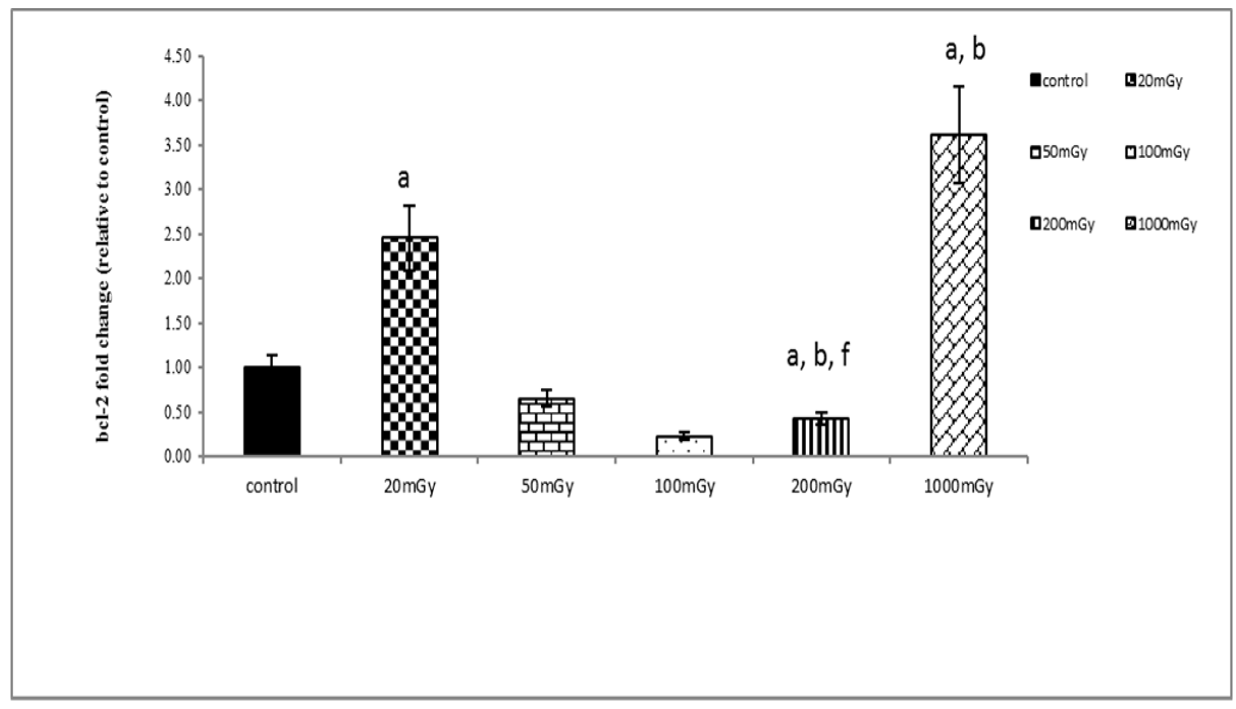

Figure 1: Effect of low-dose gamma radiation on bcl-2 expression in rat's peripheral lymphocytes $24 \mathrm{~h}$ after exposure. Vertical bars represent mean \pm SEM (standard error of mean), $\mathrm{n}=7$ for each group. ${ }^{a} p<0.05$ when compared to the control group, ${ }^{b} p<0.05$ when compared to 20 $m G y,{ }^{f} p<0.05$ when compared to $1000 \mathrm{mGy}$.

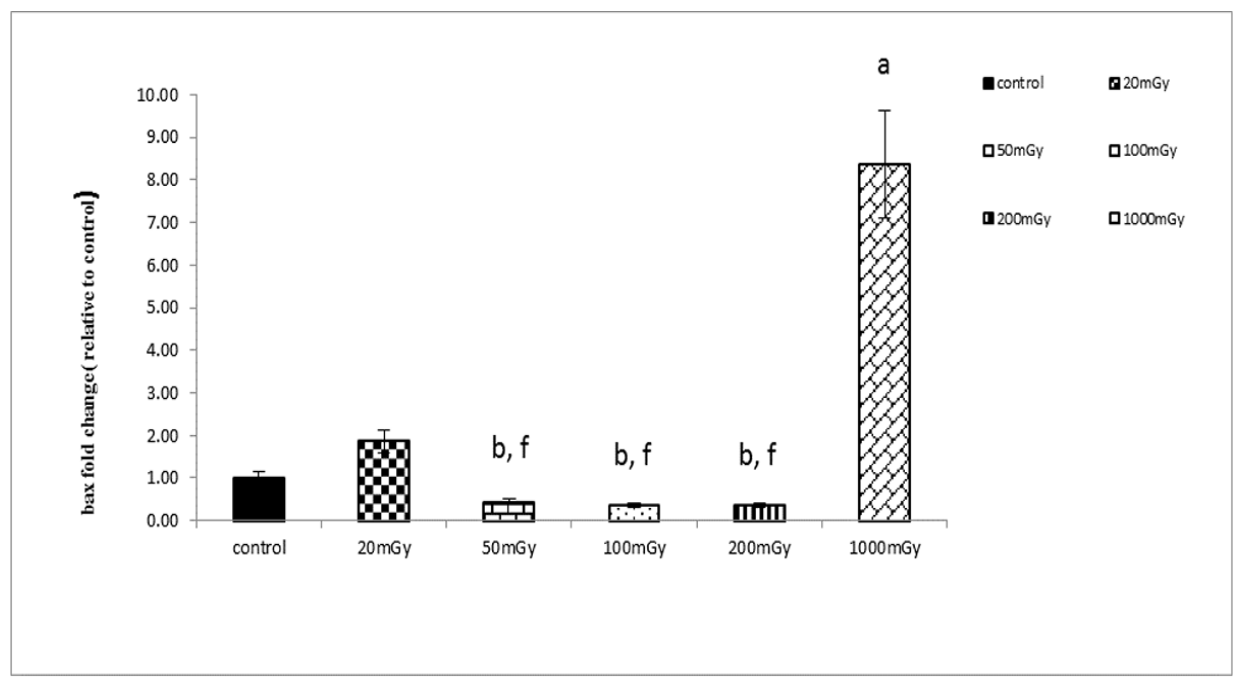

Figure 2: Effect of low-dose gamma radiation on bax expression in rat's peripheral lymphocytes $24 \mathrm{~h}$ after exposure. Vertical bars represent mean \pm SEM (standard error of mean), $\mathrm{n}=7$ for each group. ${ }^{a} p<0.05$ when compared to the control group, ${ }^{b} p<0.05$ when compared to $20 \mathrm{mGy},{ }^{f} p$ $<0.05$ when compared to $1000 \mathrm{mGy}$ 
Radio-protective Effects of Low-dose Radiation

0.001 respectively). The relative expression levels of bax gene in 50, 100 and $200 \mathrm{mGy}$ doses radiation have shown a significant decrease compared to the $20 \mathrm{mGy}$ dose $(\mathrm{p}<$ $0.001)$. In $1000 \mathrm{mGy}$ radiation dose, the relative expression of BAX gene has shown a significant increase compared with other radiation doses $(\mathrm{p}<0.001)$.

\section{Evaluation of bax/bcl-2 ratio}

In Figure 3, the bax/bcl-2 ratio was shown in six groups under study subsequent to $24 \mathrm{~h}$ exposure to cobalt gamma-60. Although the bax/bcl-2 ratio in the mGy 50 group has had a significant reduction in comparison with the control group $(p<0.05)$, this ratio has showed a significant increase in the groups exposed to 100 and $1000 \mathrm{mGy}(\mathrm{p}<0.001)$.

Exposure to 100 and 1000 mGy resulted in a significant increase of this ratio compared with 20 mGy $(p<0.001)$. In groups 100 and $1000 \mathrm{mGy}$, the ratio of bax/bcl-2 had a significant increase in comparison to the 50 mGy group $(p<0.001)$. This ratio decreased significantly in the 200 mGy radiation group compared to the $100 \mathrm{mGy}$ radiation group ( $\mathrm{p}$
$<0.001)$. However, the ratio of bax/bcl-2 had a significant increase in mice of the $1000 \mathrm{mGy}$ radiation group compared with the $100 \mathrm{mGy}$ $(\mathrm{p}<0.001)$.

\section{Discussion}

Today, in addition to exposure to natural radiation, the widespread application of ionizing radiation in various fields of human knowledge leads to human exposure inevitably [2224]. The researchers have investigated the effects of exposure (early and late) to low dose of ionizing radiation (LDIR) on human health in recent decades [25-27]. These studies have shown that tissue, cell, and molecular level responses are different after exposure to low doses of ionizing radiation (LDIR) compared with high dose of ionizing radiation (HDIR) [28]. Unlike physical dosimeters, the use of biomarkers in various scenarios such as medical imaging, occupationanal, and spatial radiation can be appropriate [29, 30]. Lymphocytes are known to be the most sensitive cells that are easily affected by apoptosis in patients undergoing radiotherapy and public $[31,32]$.

It has been shown that the abnormal expres-

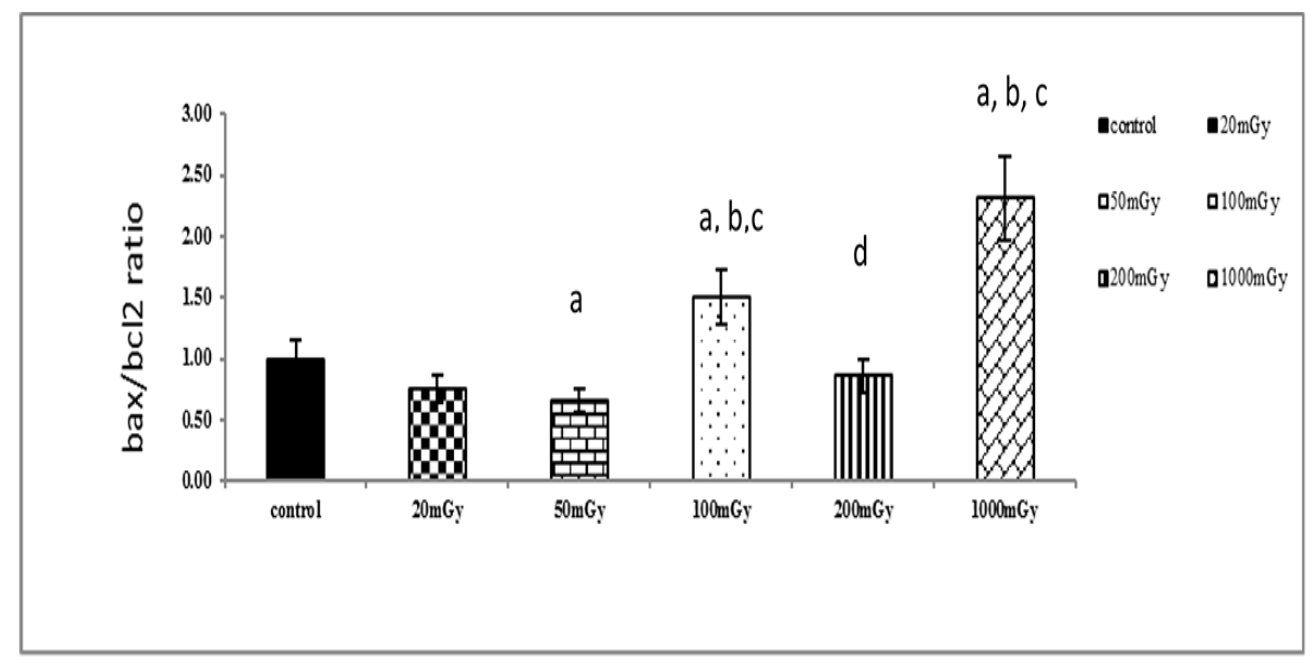

Figure 3: Effect of low-dose gamma radiation on bax expression in rat's peripheral lymphocytes $24 \mathrm{~h}$ after exposure. Vertical bars represent mean \pm SEM (standard error of mean), $\mathrm{n}=7$ for each group. ${ }^{a} p<0.05$ when compared to the control group, ${ }^{b} p<0.05$ when compared to $20 \mathrm{mGy},{ }^{c}$ $\mathrm{p}<0.05$ when compared $50 \mathrm{mGy},{ }^{d} \mathrm{p}<0.05$ when compared to $100 \mathrm{mGy},{ }^{f} p<0.05$ when compared to $1000 \mathrm{mGy}$. 
sion of bax and bcl-2 genes is closely related to radiation-induced apoptosis in peripheral lymphocytes [33]. The purpose of this study was to evaluate the effects of low-dose gamma radiation on the expression of bax and bcl-2 genes in rat peripheral blood lymphocytes. Radio-sensitivity of lymphocytes cells was measured by the bax/bcl-2 ratio (as a predictive marker for radio-sensitivity).

The results of the study carried out by Takahashi et al. showed that the radio-adaptive effects in mouse spleen may be due to a suppression of p53-mediated apoptosis [34]. Another study has also shown that the upregulation of bcl-2 and downregulation of bax can cause radiation protection responses [35].

However, the result of our study indicates that the expression of bcl-2 was found to be up-regulation at $20 \mathrm{mGy}$ at $24 \mathrm{~h}$ after gamma radiation, and bax was down-regulation at low doses of gamma radiation at $24 \mathrm{~h}$. Furthermore, in the present study, the expression of bcl-2 at 20 mGy was significantly higher than control group. bcl-2 expression significantly decreased following exposure 50, 100 and 200 mGy in compared to $20 \mathrm{mGy}$. In contrast, upregulation of bcl-2 was indicated following irradiation $1000 \mathrm{mGy}$.

Our results demonstrated a significant decrease in bax/bcl2 ratio at $24 \mathrm{~h}$ following $50 \mathrm{mGy}$ irradiation compared to control group $(\mathrm{P}<0.05)$. In contrast, $100 \mathrm{mGy}$ and 1000 mGy irradiation groups increased significantly for the bax/bcl-2 ratio $(\mathrm{p}<0.05)$. In addition, at doses of 100 and $1000 \mathrm{mGy}$, bax/bcl-2 ratio significantly increased compared with 20 mGy.

Bahreyni Toosi et al. have shown that the bax/bcl2 ratio significantly decreased at 24 $\mathrm{h}$ following irradiation $100 \mathrm{mGy}(\mathrm{P}<0.05)$. Their results were not consistent with our study. In the study of Bahreyni Toosi et al. the $\mathrm{bax} / \mathrm{bcl} 2$ ratio was significantly reduced in 20 mGy irradiation, but in our study, the maximum reduction in bax/bcl 2 ratio at $50 \mathrm{mGy}$ was observed [12]. It has been shown in sev- eral studies that the lowest dose level at which the apoptosis-induced radiation frequency was $50 \mathrm{mGy}$. These results were in line with our results [36, 37].

Our previous study showed that the percentage of apoptotic lymphocytes for 8Gy radiation dose decreased in $300 \mathrm{mGy} / \mathrm{min}$ at $24 \mathrm{~h}$ after exposure. In addition, based on the results of qPCR, in the dose of $8 \mathrm{~Gy}$, the bax expression and the ratio of bax/bcl-2 decreased significantly [17]. According to previous studies, apoptosis depends on dose value and post-exposure elapsed time. In fact, increased levels of apoptosis can explain the more damaging effects of radiation, and vice versa [4]. Our results could support the hypothesis that the radiation protection effects of low-dose radiation can be due to decrease in the bax/bcl-2 ratio leading to the increase in cell survival.

\section{Conclusion}

Based on the results obtained in this study, the low-dose gamma radiation would reduce the bax/bcl-2 ratio in irradiated rats, mainly attributed to its radio-adaptive effects.

\section{Acknowledgment}

This work was extracted from the proposal supported by the Research Council of Shiraz University of Medical Sciences (93-01-10-7703). The authors wish to thank the Research Consolation Center (RCC) at Shiraz University of Medical Sciences for his invaluable assistance in editing this manuscript.

\section{Authors' Contribution}

Reza Fardid conceived the idea. Introduction of the paper was written by Reza Fardid and Zhila Ghorbani. Zhila Ghorbani gather data and the related literature and also help with writing of the related works. The method implementation was carried out by Reza Fardid and Zhila Ghorbani. Results and Analysis was carried out by Reza Fardid and Zhila Ghorbani. The research work was proofread and supervised by Reza Fardid. All the authors read, modified, and approved the final version of the manuscript. 


\section{Ethical Approval}

The Ethics Committee of Shiraz University of Medical Sciences approved the protocol of the study (Ethic cod: IR.SUMS.REC.1395.101).

\section{Funding}

This study was supported by Shiraz University of Medical Sciences [grant number: 93-01-107703].

\section{Conflict of Interest}

None

\section{References}

1. Mettler FA Jr, Thomadsen BR, Bhargavan M, Gilley DB, Gray JE, Lipoti JA, et al. Medical radiation exposure in the U.S. in 2006: preliminary results. Health Phys. 2008;95:502-7. doi: 10.1097/01. HP.0000326333.42287.a2. PubMed PMID: 18849682.

2. El-Shanshoury H, El-Shanshoury G, Abaza A. Evaluation of low dose ionizing radiation effect on some blood components in animal model. Journal of Radiation Research and Applied Sciences. 2016;9:28293. doi: 10.1016/j.jrras.2016.01.001.

3. Brenner DJ, Doll R, Goodhead DT, Hall EJ, Land $\mathrm{CE}$, Little JB, et al. Cancer risks attributable to low doses of ionizing radiation: assessing what we really know. Proc Natl Acad Sci U S A. 2003;100:137616. doi: 10.1073/pnas.2235592100. PubMed PMID: 14610281. PubMed PMCID: PMC283495.

4. Rezaeejam H, Shirazi A, Valizadeh M, Izadi P. Candidate gene biodosimeters of mice and human exposure to ionizing radiation by quantitative reverse transcription polymerase chain reaction. J Cancer Res Ther. 2015;11:549-57. doi: 10.4103/09731482.160912. PubMed PMID: 26458580.

5. Swartz HM, Williams BB, Flood AB. Overview of the principles and practice of biodosimetry. Radiat Environ Biophys. 2014;53:221-32. doi: 10.1007/s00411014-0522-0. PubMed PMID: 24519326. PubMed PMCID: PMC5982531.

6. Amundson SA, Bittner M, Meltzer P, Trent J, Fornace Jr AJ. Biological indicators for the identification of ionizing radiation exposure in humans. Expert Rev Mol Diagn. 2001;1:211-9. doi: 10.1586/14737159.1.2.211. PubMed PMID: 11901816.

7. Sudprasert $W$, Navasumrit $P$, Ruchirawat M. Effects of low-dose gamma radiation on DNA damage, chromosomal aberration and expression of repair genes in human blood cells. Int J Hyg Environ Health. 2006;209:503-11. doi: 10.1016/j.ijheh.2006.06.004. PubMed PMID: 16872898.
8. Verma AR, Vijayakumar M, Rao CV, Mathela CS. In vitro and in vivo antioxidant properties and DNA damage protective activity of green fruit of Ficus glomerata. Food Chem Toxicol. 2010;48:704-9. doi: 10.1016/j.fct.2009.11.052. PubMed PMID: 19951737.

9. Azzam El, Jay-Gerin JP, Pain D. Ionizing radiation-induced metabolic oxidative stress and prolonged cell injury. Cancer Lett. 2012;327:48-60. doi: 10.1016/j. canlet.2011.12.012. PubMed PMID: 22182453. PubMed PMCID: PMC3980444.

10. Kaina B. DNA damage-triggered apoptosis: critical role of DNA repair, double-strand breaks, cell proliferation and signaling. Biochem Pharmacol. 2003;66:154754. doi: 10.1016/s0006-2952(03)00510-0. PubMed PMID: 14555233.

11. Karran P. DNA double strand break repair in mammalian cells. Curr Opin Genet Dev. 2000;10:144-50. PubMed PMID: 10753787.

12. Azimian H, Bahreyni-Toossi MT, Rezaei AR, Rafatpanah $\mathrm{H}$, Hamzehloei T, Fardid R. Up-regulation of Bcl-2 expression in cultured human lymphocytes after exposure to low doses of gamma radiation. J Med Phys. 2015;40:38-44. doi: 10.4103/09716203.152249. PubMed PMID: 26150686. PubMed PMCID: PMC4471643.

13. Cui $Y$, Yang H, Wu S, Gao L, Gao Y, Peng R, et al. Molecular mechanism of damage and repair of mouse thymus lymphocytes induced by radiation. Chin Med J (Engl). 2002;115:1070-3. PubMed PMID: 12150745.

14. Cui YF, Ding YQ, Xu H, Jiang ZJ, Liu XL, Dong B, et al. Relationship between apoptosis of mouse thymic lymphocytes and expressions of bax, bcl-2 and bcl-XL after gamma-ray radiation with lethal dose. $X i$ Bao Yu Fen Zi Mian Yi Xue Za Zhi. 2004;20:750-3. PubMed PMID: 15555453.

15. Azimian H, Dayyani M, Toossi MTB, Mahmoudi M. Bax/Bcl-2 expression ratio in prediction of response to breast cancer radiotherapy. Iran $\mathrm{J} \mathrm{Ba}$ sic Med Sci. 2018;21:325-32. doi: 10.22038/ IJBMS.2018.26179.6429. PubMed PMID: 29511500. PubMed PMCID: PMC5817177.

16. Haddadi G, Abbaszadeh A, Mosleh-Shirazi MA, Okhovat MA, Salajeghe A, Ghorbani Z. Evaluation of the effect of hesperidin on vascular endothelial growth factor gene expression in rat skin animal models following cobalt-60 gamma irradiation. J Cancer Res Ther. 2018;14:S1098-S104. doi: 10.4103/09731482.202892. PubMed PMID: 30539852.

17. Fardid R, Ghorbani Z, Haddadi G, Behzad-Behbahani A, Arabsolghar R, Kazemi E, et al. Effects of Hesperidin as a Radio-protector on Apoptosis in Rat Peripheral Blood Lymphocytes after Gamma Radiation. J Biomed Phys Eng. 2016;6:217-28. PubMed PMID: 28144590. PubMed PMCID: PMC5219572. 
18. Hamivand Z, Haddadi G, Fardid R. Expression of Bax and Bcl2 Genes in Peripheral Blood Lymphocytes of Patients with Differentiated Thyroid Cancer. J Med Phys. 2018;43:41-5. doi: 10.4103/jmp. JMP_104_17. PubMed PMID: 29628632. PubMed PMCID: PMC5879822.

19. Furlong H, Mothersill C, Lyng FM, Howe O. Apoptosis is signalled early by low doses of ionising radiation in a radiation-induced bystander effect. Mutat Res. 2013;741-742:35-43. doi: 10.1016/j. mrfmmm.2013.02.001. PubMed PMID: 23454491.

20. Hussein MR. Apoptosis in the ovary: molecular mechanisms. Hum Reprod Update. 2005;11:16277. doi: 10.1093/humupd/dmi001. PubMed PMID: 15705959.

21. Pfaffl MW. A new mathematical model for relative quantification in real-time RT-PCR. Nucleic Acids Res. 2001;29:e45. doi: 10.1093/nar/29.9.e45. PubMed PMID: 11328886. PubMed PMCID: PMC55695.

22. Turner ND, Braby LA, Ford J, Lupton JR. Opportunities for nutritional amelioration of radiation-induced cellular damage. Nutrition. 2002;18:904-12. doi: 10.1016/s0899-9007(02)00945-0. PubMed PMID: 12361786.

23. Brambilla M, De Mauri A, Lizio D, Matheoud R, De Leo M, Carriero A. Estimated radiation risk of cancer from medical imaging in haemodialysis patients. Nephrol Dial Transplant. 2014;29:1680-6. doi: 10.1093/ndt/gfu080. PubMed PMID: 24737442.

24. Zeegers D, Venkatesan S, Koh SW, Low GK, Srivastava P, Sundaram N, et al. Biomarkers of Ionizing Radiation Exposure: A Multiparametric Approach. Genome Integr. 2017;8:6. doi: 10.4103/20419414.198911. PubMed PMID: 28250913. PubMed PMCID: PMC5320786.

25. Burgio E, Piscitelli P, Migliore L. Ionizing Radiation and Human Health: Reviewing Models of Exposure and Mechanisms of Cellular Damage. An Epigenetic Perspective. Int J Environ Res Public Health. 2018;15. doi: 10.3390/ijerph15091971. PubMed PMID: 30201914. PubMed PMCID: PMC6163535.

26. Tanaka K, Kohda A, Satoh K. Dose-rate effects and dose and dose-rate effectiveness factor on frequencies of chromosome aberrations in splenic lymphocytes from mice continuously exposed to low-doserate gamma-radiation. J Radiol Prot. 2013;33:61-70. doi: 10.1088/0952-4746/33/1/61. PubMed PMID: 23295730.

27. Sevan'kaev AV, Khvostunov IK, Potetnia VI. The low dose and low dose rate cytogenetic effects induced by gamma-radiation in human blood lymphocytes in vitro. I. the results of cytogenetic study. Radiats Biol Radioecol. 2012;52:11-24. PubMed PMID: 22568009.

28. Matsumoto H, Hamada N, Takahashi A, Kobayashi Y, Ohnishi T. Vanguards of paradigm shift in radiation biology: radiation-induced adaptive and bystander responses. J Radiat Res. 2007;48:97-106. doi: 10.1269/jrr.06090. PubMed PMID: 17327685.

29. Pannkuk EL, Fornace Jr AJ, Laiakis EC. MetaboIomic applications in radiation biodosimetry: exploring radiation effects through small molecules. Int J Radiat Biol. 2017;93:1151-76. doi: 10.1080/09553002.2016.1269218. PubMed PMID: 28067089. PubMed PMCID: PMC5507746.

30. Ghandhi SA, Smilenov LB, Elliston CD, Chowdhury $\mathrm{M}$, Amundson SA. Radiation dose-rate effects on gene expression for human biodosimetry. BMC Med Genomics. 2015;8:22. doi: 10.1186/s12920-0150097-x. PubMed PMID: 25963628. PubMed PMCID: PMC4472181.

31. Bahreyni-Toossi MT, Fardid R, Rezaee A, Sadrnabavi $A$, Rafatpanah $H$, Bolbolian $M$. Expression of apoptotic genes can distinguish radiation workers from normal population. International Journal of Low Radiation. 2011;8:388-99. doi: 10.1504/ ijlr.2011.047184.

32. Karbownik M, Reiter RJ. Antioxidative effects of melatonin in protection against cellular damage caused by ionizing radiation. Proc Soc Exp Biol Med. 2000;225:9-22. doi: 10.1046/j.15251373.2000.22502.x. PubMed PMID: 10998194.

33. Cui YF, Gao YB, Yang H, Xiong CQ, Xia GW, Wang DW. Apoptosis of circulating lymphocytes induced by whole body gamma-irradiation and its mechanism. J Environ Pathol Toxicol Oncol. 1999;18:1859. PubMed PMID: 15281231.

34. Takahashi A, Ohnishi K, Asakawa I, Kondo N, Nakagawa $\mathrm{H}$, Yonezawa $\mathrm{M}$, et al. Radiation response of apoptosis in C57BL/6N mouse spleen after wholebody irradiation. Int J Radiat Biol. 2001;77:939-45. doi: 10.1080/09553000110062873. PubMed PMID: 11576453.

35. Mohseni M, Mihandoost E, Shirazi A, Sepehrizadeh Z, Bazzaz JT, Ghazi-khansari M. Melatonin may play a role in modulation of bax and bcl-2 expression levels to protect rat peripheral blood lymphocytes from gamma irradiation-induced apoptosis. Mutat Res. 2012;738-739:19-27. doi: 10.1016/j.mrfmmm.2012.08.006. PubMed PMID: 22982225.

36. Wilkins RC, Wilkinson D, Maharaj HP, Bellier PV, Cybulski MB, McLean JR. Differential apoptotic response to ionizing radiation in subpopulations of human white blood cells. Mutat Res. 2002;513:2736. doi: 10.1016/s1383-5718(01)00290-x. PubMed PMID: 11719087.

37. Korsmeyer SJ, Wei MC, Saito M, Weiler S, Oh KJ, Schlesinger PH. Pro-apoptotic cascade activates BID, which oligomerizes BAK or BAX into pores that result in the release of cytochrome c. Cell Death Differ. 2000;7:1166-73. doi: 10.1038/sj.cdd.4400783. PubMed PMID: 11175253. 